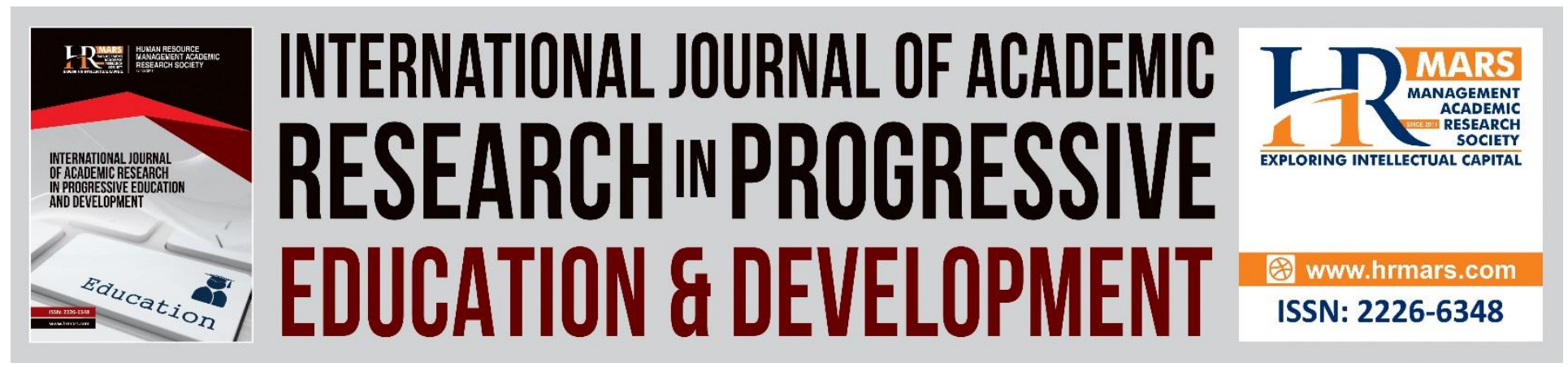

\title{
Higher Order Thinking Skills (HOTs): Acting Method as Approach of Critical Pedagogy in Education Culture
}

Mohd Azly Zakaria, Muhammad Faisal Ahmad, Mohd Kipli Abdul Rahman

To Link this Article: http://dx.doi.org/10.6007/IJARPED/v10-i2/10132

DOI:10.6007/IJARPED/v10-i2/10132

Received: 05 April 2021, Revised: 28 April 2021, Accepted: 20 May 2021

Published Online: 09 June 2021

In-Text Citation: (Zakaria et al., 2021)

To Cite this Article: Zakaria, M. A., Ahmad, M. F., \& Rahman, M. K. A. (2021). Higher Order Thinking Skills (HOTs): Acting Method as Approach of Critical Pedagogy in Education Culture. International Journal of Academic Research in Progressive Education and Development, 10(2), 502-516.

Copyright: (C) 2021 The Author(s)

Published by Human Resource Management Academic Research Society (www.hrmars.com)

This article is published under the Creative Commons Attribution (CC BY 4.0) license. Anyone may reproduce, distribute, translate and create derivative works of this article (for both commercial and non-commercial purposes), subject to full attribution to the original publication and authors. The full terms of this license may be seen at: http://creativecommons.org/licences/by/4.0/legalcode

Vol. $10(2)$ 2021, Pg. 502 - 516

http://hrmars.com/index.php/pages/detail/IJARPED JOURNAL HOMEPAGE

Full Terms \& Conditions of access and use can be found at http://hrmars.com/index.php/pages/detail/publication-ethics 


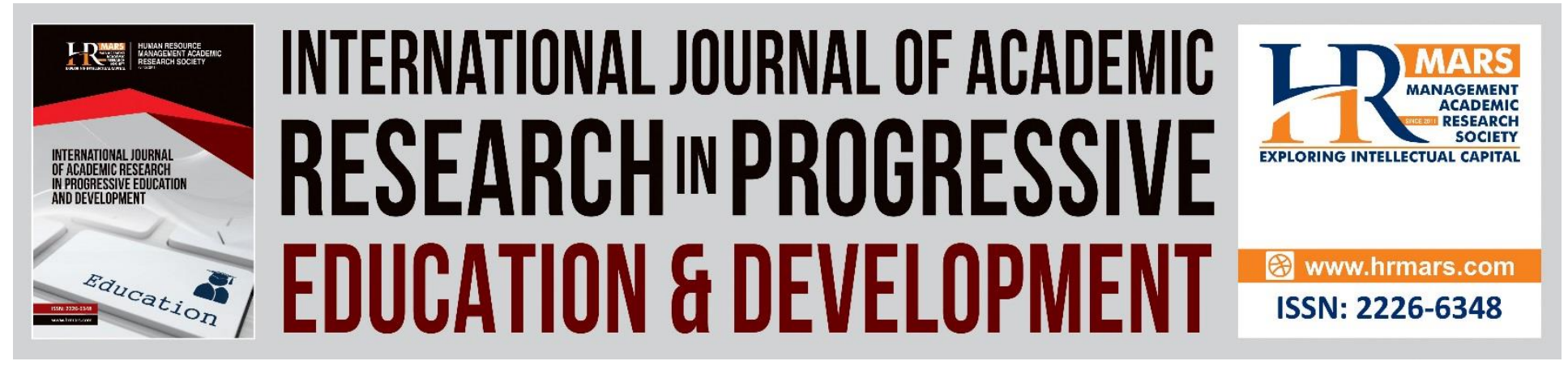

\title{
Higher Order Thinking Skills (HOTs): Acting Method as Approach of Critical Pedagogy in Education Culture
}

\author{
Mohd Azly Zakaria, Muhammad Faisal Ahmad, Mohd Kipli Abdul \\ Rahman
}

Faculty of Music and Performing Arts Sultan Idris Education University Malaysia

\begin{abstract}
The writing of this social science concept paper is conducted to explore the elements acting method implementation a Higher Order Thinking Skills (HOTs) in education. Therefore, by researching the understanding of Secondary School Standard Curriculum (KSSM) in the implementation of Higher Order Thinking Skills (HOTs), and how teachers make critical transformations Incorporate into the teaching plan, and implement teaching through the curriculum. The research was intended to introduce the modification of the acting method as an alternative method or known as critical pedagogy to strengthening the student aspirations. In addition, the acting method in depth through the transformation approach of Theater Arts such as Constantine Stanislavky (1946), Bertolt Brecht (1956) and Augusto Boal (1978). The culture of education in Malaysia, which is still based on a teacher-centered pedagogical approach, raises the question of the extent to which Higher Order Thinking Skills (HOTs) can be implemented more comprehensively by using the acting method in teacher pedagogical. This article discusses the critical pedagogy idea pioneered by Paulo Freire (1970) for creating the transformation of educational culture towards the curriculum. The design of this study is qualitative and case study strategy. The implication of this article is the need to transform the culture of teaching and learning to be more open, friendly, and not too formal as well as to celebrate the diversity of students' ideas through acting techniques. Teachers play an important role in determining the direction of teaching and forming creative, innovative, critical thinking, ethical and disciplined values. This study also provides some suggestions to improve the development of teacher professional identity and Develop guides and reference materials for professional theater and drama programs in education and culture as approaches of the Malaysian Ministry of Education (MOE) and the Ministry of Higher Education (MOHE).

Keywords: Higher Order Thinking Skills, Critical Pedagogy, Curriculum Development, Acting Method, Education Culture
\end{abstract}




\section{Introduction}

Theater in education began at Belgrade Conventry in 1965 in Britain. At that time Belgrade, the theater was developed by a group of teachers and members of community leaders by exploring cultural, social, political, and moral issues aimed at providing free education to the young people there. In 1960, there was a worldwide movement as a result of the Second World War until a revolution broke out in the world of education and led to the establishment of many companies that offer theater services in education (Redington, 2003). Furthermore, the community began to realize that theater techniques are very useful to foster more effective learning in the world of education. Theater in education is an activity of art integration in the process of educational delivery that occurs directly through activities encompassing space and environment. As a whole, every community especially teachers, parents, and students agree that the idea of educational vision is a medium towards holistic development of students in terms of intellectual, spiritual, emotional, and physical.

Similarly, efforts to improve the education system have become the basis for supporting the balance of the National Education Philosophy (FPK) which is also the core of aspirations for students in Malaysia. Thus, this plan has outlined six important characteristics mastered by each student to enable them to lead intellectual and global development in time next. The six student aspirations that have been outlined are knowledge, thinking skills, leadership skills, bilingual skills, ethics and spirituality, and national identity. All elements of student aspirations are applied to students through the process of teaching and learning taking place in school, during cocurricular activities, or during certain programs conducted in school. Emphasis on student aspirations is important to produce first-class human capital that is competitive, efficient, resilient, and flexible when faced with workplace situations. Turning to the theatrical method to be used in this study, the researcher chose the Acting Method invented by Stanislavski (1949). He has outlined 15 methods or principles that an actor can practice. Among them are the magic if, given circumstances, emotional and spiritual, imagination, adaptation, observation, and others (Stanislavski, 2013). The Acting Method acts as a guideline for an actor to bring their acting quality on stage with the aim of injecting creative aspects and innovation in creating character diversity. A variety of methods will provide space for actors to make choices to facilitate the training process to achieve their goals.

Higher Order Thinking Skills (HOTs) is now an important agenda in education in Malaysia. In the context of primary schools, the element of reasoning is the latest element in the curriculum which is emphasized by the Ministry of Education (MOE) after the elements of reading, writing, and counting (MOE, 2013). The addition of this element of reasoning is associated with HOTs because reasoning ability involves the ability of students to think critically, creatively, logically, and rationally in accordance with the problems that students want to solve in the learning process. High Order Thinking Skills (HOTs) is the ability to apply knowledge, skills, and valuesin reasoning and reflection to solve problems, make decisions, innovate and be able to create something (Examinations Syndicate, 2013). This means that HOTS requires a process of intellectual thinking skills with broad and deep thinking whether it is finding meaning and understanding of something, making judgments and decisions, or solving problems. In the context of secondary school, more elements of HOTs are applied through assessment questions that require students to think at a more complex level and not just spit out any answers that 
students learn in the classroom. In short, HOTs requires students to think as someone who is able to provide sustainable, practical, useful, and acceptable solutions to problems of the rational mind.

However, HOTs is not easy to implement in Malaysia. Although various efforts have been made to train teachers and students to use HOTs in the teaching and learning process, the status quo of education in Malaysia is the dominance of teacher-centered teaching (Thomas \& Watters, 2015). So, by probing the understanding of Pedagogical Content Knowledge (PCK) by Shulman (1986) through the Secondary School Standard Curriculum (KSSM KSSM), Malaysian Arts School (SSeM) instill an alternative method as critical pedagogy in the execution of education culture. Why and how should this pedagogy teacher-centered training be transfigured to studentcentered to achieve the goals of HOTs? This paper attempts to unravel questions involving critical pedagogy that place emphasis on aspects of freedom of debate and the goals of education itself. The Ministry of Education (MOE) of Malaysia has launched the Malaysia Education Blueprint (PPPM, 2013-2025), which focuses on ideas related to the place of teachers as facilitators. A plan has issued guidelines and goals to be achieved in Malaysian education. Since 2011, the Ministry of Education has enforced curriculum reforms through the execution of the Secondary School Standard Curriculum (KSSM). The development of this course was thereafter helped with the execution of KSSM (revised edition) in 2017. The new curriculum focuses on abilities, knowledge, skills, and competencies to find the need to transfigure 21st-century education into an important transformation. The Ministry of Education encourages teachers to take constitution development drive to help knowledge and skill of pedagogy and to espouse new training practices that can meet the necessaries of the 21st century, as described in PPPM 20132025. Effective and efficient teachers in the training process are the main indicators to measure the success of students and can engender creative, innovative, and critical thinking (Rahman, Jamaludin \& Zamri, 2015).

\section{Problem Statement}

Problems exist when the education system in Malaysia through the first phase shift of the Malaysian Education Development Blueprint starting 2013-2025 in improving the quality of the teaching profession and the aspirations of students require them to have Higher Order Thinking Skills (HOTs) in the Malaysian Education Development Plan 2013-2025. This is very much in line with the learning needs of the 21st Century but the findings of the study, low performing school students still do not support the mastery of thinking skills (Rajendran, 2014). Seman (2005) found that teachers often give questions that focus on low-level questioning to students at the level of knowledge and understanding and less use the high-level questioning approach. Rajendran (2014) stated that Lower Order Thinking Skills (LOTs) refer to the limited use of thinking. This can be seen when students are only provided with answers that make them not critical in thinking.

Now, the problem where students are found to be weak in thinking in basic learning or basic knowledge on external and internal factors according to Chee et al. (2018). Cathrine (2019) has identified several problems faced by teachers, namely teachers lack of knowledge and pedagogical techniques in delivering the teaching and learning process. These findings are in line with the views of Rajendran (2014) that low level questions are very popular used by teachers 
and very few high levels questions are given to students at the same time students can not think outside the box and increase the level of intelligence.

According to Gardner (1983), there are elements of intelligence such as kinesthetics, music, or movement by the teacher or educator in the delivery of dialogue such as tone stress, rhythm and dynamics in learning help pronunciation and appreciation in the delivery of dialogue and improvisation in mimic and pose in reflecting the teacher's teaching effectively and attract the interest of students. Studies on the acting method in line with teaching are still limited. One aspect that has never been taken seriously among educators is that gesture art or a term in the context of the acting method is referred to as improvisation in character creation and characterization as a teacher (Faisal, 2012) and is supported by Fadhilah (2014) and Azly (2016).

Through creative drama, creative theater and reader's theater in the 21st century to carry out in-depth critical teaching methods and interesting learning teaching, such as project-based learning, problem-based learning and cross-curricular teaching activities using inquiry approaches (Laksmi \& Kipli, 2017). In addition to supporting the training of national creative industries to solve problems, decision-makers and creative, innovative and critical thinking, it also refers to the National Creative Industry Policy (DIKN, 2010).

Teachers still lack knowledge of curriculum content and pedagogy, and cannot be applied to critical pedagogy. Knowledge needs to be imparted to the learning activities of an integrated manner Azmi and Nurzatulshima (2017). Teachers need to be proficient in various teaching techniques such as acting skills and provide students with various learning needs with opportunities to explore their greatest potential, interest, and critical thinking. Here, creativity is an important element that can enhance teachers' abilities, enabling them to generate and use as many ideas and technologies as possible, and effectively exchange new ideas in educational culture.

The Ministry of Education has implemented curriculum reforms through the implementation of the Secondary School Standard Curriculum (KSSM) since 2011 and revised it in 2017 (MOE, 2017). According to Azly (2021), teachers who teach new subjects have problems in mastering the content and teaching methods suitable for the subject. In addition, the nonspecialization of teachers in any particular subject will lead to a decline in creativity and innovation in teaching practice, while students tend to become more passive and not produce any critical thinking (Saleh et al., 2018).

In addition, in the context of dealing with the challenges of the globalized world and the key elements of the challenges facing the 21st-century learning era, teachers still lack the understanding of the importance of teaching skills and knowledge. Teachers are responsible for using various meaningful techniques and methods in teaching to actively maintain students' interest and motivation (Iberahim, Mahamod \& Mohamad, 2017). From the perspective of confidence in the implementation of teaching and learning, non-professional or not expertise in field teachers lack confidence in conveying information, and effective communication between teachers and students is usually less (Paolucci \& Dwyer, 2017; Plessis, 2018). Compared with teachers who have specialized knowledge in teaching topics, the ability of teachers to control the curriculum in the teaching process is not specialized knowledge (Kam et al., 2018).

Therefore, this research is necessary to test how teachers conduct teaching practice through Freire's (1970) critical pedagogy method. In addition, this research needs to identify and 
Vol. 10, No. 2, 2021, E-ISSN: $2226-6348$ @ 2021 HRMARS

explore transformational teaching through knowledge and skills. The knowledge and skills refer to the content and assessment standard document (DSKP), the learning objectives in the secondary school standard curriculum (KSSM), in order to carry out key transformations to achieve the eighth eighth shift "Transformation of Educational Abilities and Delivery Capabilities" in the third wave of the Malaysia Education Blueprint 2013-2025.

\section{Aim and Research Questions}

The aim behind this research study is to explore and understand in depth the elements of acting adapted from the acting techniques in critical pedagogy from Paulo Freire (1970). This study aims to answer the following research questions:

1. What is the prior knowledge and skills of the acting method by the teacher in line with teaching?

2. How acting method in stimulating Higher Order Thinking Skills (HOTs) among students?

3. How critical pedagogy in the implementation of education culture?

\section{Literature Review}

\section{Critical Pedagogy and Education Culture}

Critical pedagogy is a form of educational reform movement pioneered by Paulo Freire in his influential writing, Pedagogy of the Oppressed by Freire (1970) proposed the idea that pedagogy relies on the centralization of ideas to an individual (such as a teacher or leader) encourages a culture of silence or lack of courage in providing views or ideas. Freire uses the term banking education to describe a form of pedagogy that assumes that students are like an empty vassal and teachers play a role in filling empty containers with deposits (i.e. knowledge or ideas). In Freire's view, this critical pedagogical approach is contrary to the goal of education which is to liberate human beings from the colonization of the mind, oppression, and domination by oppressors. Education should free human beings from these oppressions and move towards harmony between the learner and the taught i.e. the student and the teacher. The banking education approach is similar to the behaviorism approach which also sees students or learners as empty containers that need to be filled with various ideas with stimulus-response relationships. In the Malaysian context, the status quo in education still shows the dominance of teacher-centered approaches (Thomas \& Watters, 2015). Although various efforts have been made to transform the teaching and learning approach to be more student-centered, these efforts have not yet succeeded in showing concrete results.

The question is, what are the implications of the status quo of education in Malaysia, namely the teacher-centered approach, from the perspective of HOTs and critical pedagogy? The implication that can be seen is the difficulty of building a culture of HOTs that is deeply rooted in schools and classrooms. When teachers still dominate the teaching and learning process, students have minimal opportunity to voice views, ideas, and solutions. Moreover, students are not able to actively participate in the teaching and learning process because the structure and culture of teaching and learning limit them to challenge each other's ideas. In fact, challenging the idea of the teacher himself is not something that can be easily accepted by teachers because it is considered against the norms of a Malaysian education culture that wants teachers to be respected. 
Approchment in implementing a more student-centered pedagogy, students need to be given more opportunities and freedom to voice their opinions. Although the student's ideas may be inaccurate compared to standard facts seemingly misconceptions in any subject, it is a form of learning from mistakes. In this case, the teacher's openness to the students 'questions and ideas is demanded. Celebrating student ideas allows teachers to learn how their students think and how it can be input in enriching the teaching and learning process itself.

Due to this, giving students more flexibilities and privileges and even allowing students to learn from their own mistakes during the teaching and learning process can create an atmosphere of teaching and learning that is open, harmonious, mutual respect, and more than that is lively. In the context of postmodernism education, critical pedagogy is reflecting our education culture in advance.

\section{Higher Order Thinking Skills and Critical Transformation}

Higher Order Thinking Skill is a process of thinking of learners at a higher cognitive level that is developed from various concepts and methods of cognitive and learning taxonomy such as problem-solving methods, bloom taxonomy, and taxonomy of learning, teaching, and assessment (Rajendran, 2001). These higher order thinking skills include problem-solving skills, creative thinking skills, critical thinking, argumentative skills, and decision-making skills. According to Bloom's Cognitive Taxonomy (1956), high order thinking skills include critical, logical, reflective, metacognitive, and creative thinking, while according to Newman and Wehlage (1993) with high order thinking learners will be able to distinguish ideas or ideas clearly, arguably well, able to solve problems, able to construct explanations, able to hypothesize and understand complex things more clearly. According to Kurniati (2014), high order thinking skills will occur when a person associates new information with information already stored in his memory and associates it and/or rearranges and develops the information to achieve a goal or find a solution to a situation. Which is difficult to solve.

The main purpose of high order thinking skills are how to improve the thinking ability of learners at a higher level, especially related to the ability to think critically in receiving various types of information, think creatively in solving a problem using their knowledge and make decisions in complex situations (Rajendran, 2014). The concept of higher order thinking skills is based on several opinions, as can be seen in the following table:

Table 1. Policy and Concept of Higher Order Thinking Skills

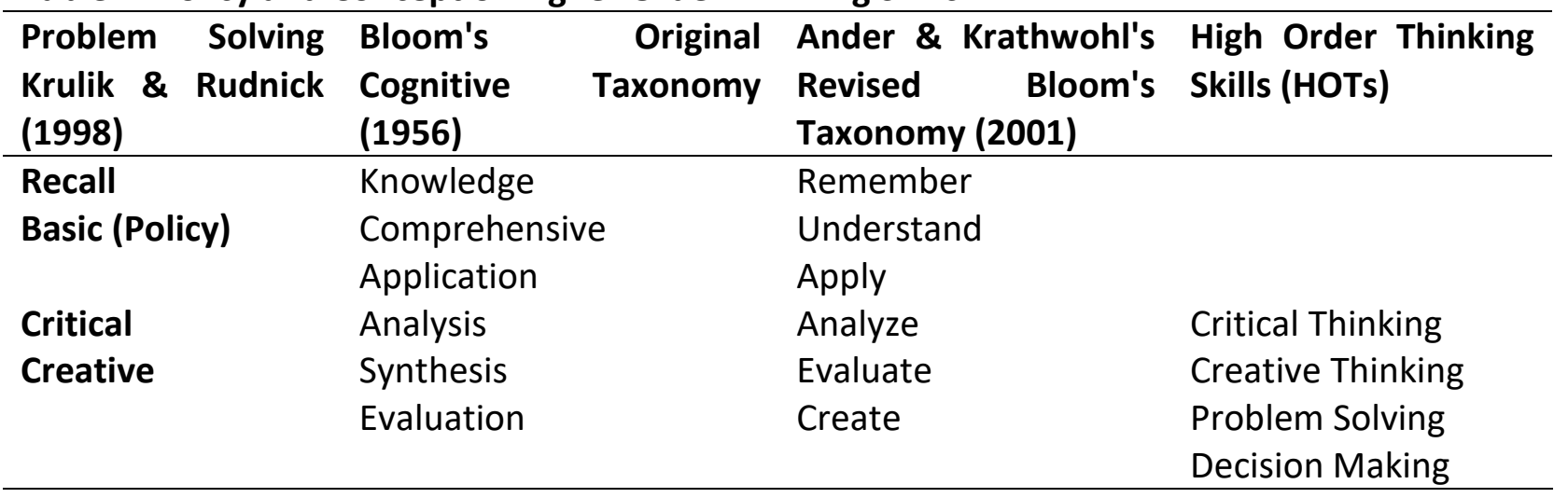


Problem Solving according to Krulik \& Rudnick (1998) is a process, meaning that each an individual uses the acquired knowledge, skills, understanding which is then used in new situations. The process begins by comparing and concluding then learners must integrate what they have learned and apply it to new situations. Problem-solving patterns according to Krulik \& Rudnick (1998) are described in steps that can be taught to learners, namely, (1) reading a problem, (2) developing information, (3) choosing a strategy, (4) solving a problem, and (5) reexamine and expand.

Thus, as seen in the table above, Bloom (1965) divides the cognitive domain into six levels of thinking, namely, (1) knowledge of recalling information that has been learned, (2) comprehension or understanding of the meaning of the material, (3) application, and applying knowledge to new situations. and situations that have never been experienced before or apply rules or principles, (4) analysis, identifying and understanding parts of material or whole material, (5) synthesis, combining elements to form a new whole, and (6) evaluation, examine or evaluate carefully based on several criteria.

The revision of Bloom's taxonomy by Anderson \& Krathwohl (2001) focuses more on how cognitive domains are more vivid and applicative for educators and learning practices that are expected to assist educators in processing and formulating efficient learning objectives and assessment strategies. The above three concepts that form the basis of higher order thinking skills refer to the activities of analyzing, evaluating, creating knowledge that is adapted to the conceptual, procedural and metacognitive. According to Krathwohl (2002) in a revision of Bloom's Taxonomy, states that indicators for measuring high-level thinking ability include analyzing (C4) which is the ability to separate concepts into several components and connect each other to gain an understanding of the concept as a whole, evaluate (C5) that is the ability to determine the degree of something based on certain norms, criteria, or criteria, and create (C6) that is the ability to combine elements into something new form that is whole and broad, or make something original.

Based on the critical pedagogical approach and the status quo of education in Malaysia, the most demanded critical transformation to bring is a cultural transformation in Malaysia's education process. This involves changes in teacher beliefs and attitudes, changes in teaching skills and practices, and measures to give students more opportunities and freedom in the teaching and learning process. The most practical step for the presence of elements of acting is to balance a teacher-centered pedagogy approach with student-centered pedagogy. This balance can be seen as a form of transition step towards the use of student-centered pedagogy as a whole in the future.

Besides, with various constraints inherent in the education system such as large class sizes and large numbers of students as well as limited teaching and learning time, it is quite difficult to see this transformation happening radically and quickly. For that reason, this critical transformation process is expected to be slow but sure.

The culture of teacher-centered in the classroom should be replaced with a culture of sharing opinions with a student-centered platform. It is impossible for classrooms to be lively with new ideas if teachers still dominate the teaching and learning process. Therefore, every a teacher must be prepared to implement pedagogical and critical transformation towards the use of critical pedagogy in the elements of acting that can empower students and create a teaching 
Vol. 10, No. 2, 2021, E-ISSN: 2226-6348 @ 2021 HRMARS

and learning environment that generates critical and creative thinking of students in line with the goals of Higher Order Thinking Skills (HOTs).

\section{Strengthening Thinking Skills Using the Stanislavsky Acting Method}

The success of an educational institution in disseminating and developing student aspirations among students is highly dependent on the credibility and skills of a teacher to implement a quality teaching and learning process in schools (Nadiha, 2011). Therefore, a holistic approach and critical pedagogy should be used for every teacher in order to form students who can compete globally in terms of knowledge, thinking skills, leadership skills, bilingual skills, ethics and spirituality and national identity. For this advanced social science in education study, the researcher only focused on one technique from Stanislavsky's Acting Method, namely observation. A total of three aspects were assessed through thinking skills strengthening activities absorbed through this technique.

The first aspect is the aspect of creative and innovative thinking that focuses on awareness and understanding of how society / individual / character is emotional, speaks, thinks, behaves, and uses it to build a trustworthy character. The second aspect is the aspect of critical thinking and reasoning. This aspect will focus on the act of observing, understanding, and analyzing the real community/individuals around them about how they respond, interact and communicate with feelings, emotions, and empathy. The third aspect involves the ability aspect of the student. This aspect focuses on the ability to voice and express thoughts, ideas and information confidently based on observations of spirituality, attitudes, and values through reasoning and evaluation in a reasonable, logical, and rational manner. The implementation of thinking skills strengthening activities using the Stanislavski Acting Method from observation refers to the new curriculum Theater Arts in Malaysian Arts School (BPK, 2017).

This previous study proves that strengthening students' aspirations using theater techniques is an effective method or approach that will build innovative teaching alternatives in the future (Nadhilah, 2018). In addition, the application of students' aspirations through the integration of theater into education in a planned manner allows the delivery of lesson content to run clearly and more meaningful and fun because it is more practical. In conclusion, a well planned strategy, the right approach, and efficient implementation are very important to overcome any problems that arise. In the school context, the creation of a creative learning environment is a necessity to stimulate interest in a student. It is the responsibility of the teacher to ensure that the students are not bored and always focus on teaching and learning activities in the classroom. Thus, theater activities are seen as a fun medium in conveying the message in addition to having the most intimate relationship with the community because it contains a variety of sad stories that are close to the soul and norms of current life. Hence students will experience experiences that motivate themselves with positive, creative, and critical thinking in a deep and meaningful way. Completely through this study, the theatrical technique approach of Method of Acting is hoped to succeed in nurturing and generating characteristics of thinking skills in student's aspirations in secondary schools thus being pushed to the maximum level. 
Vol. 10, No. 2, 2021, E-ISSN: 2226-6348 @ 2021 HRMARS

\section{Methodology}

The research methodology involved primary sources in field research and secondary in library research. The design of the study was conducted qualitatively on the teachers involved. Scopes such as study strategy, study location, study participants, study instruments, field studies, data collection methods, emphasized considerations, study procedures, and data analysis emphasized by the researcher in the methodology. As research instruments, interview forms, and observation checklists were provided in addition to teaching documents. The research process, which takes six months to begin, requires an application to conduct research at the MOE, University, State Department, District Department, and the school.

Researchers use the method of describing, understanding, and interpreting a problem qualitatively because they want to get insights and ideas in depth (Merriam, 2009). Case studies are appropriate for research strategies that are necessary for in-depth and thorough investigation (Merriam, 2001; Yin, 2009). This study selected five teachers as study informants who work in five zones of Malaysia Arts School in Malaysia. Each teacher for each school will be interviewed to obtain the findings of the study using an interview form and a checklist of observations through a field study. Based on the selection of each school, this study can see indepth how teachers carry out the responsibility of imparting knowledge to students in different environments according to academic background and academic performance to stimulates their higher order thinking skills.

Data collection through interview and observation methods. Content analysis of teaching documents is also used as a method of data collection. Data were analyzed for the process of identifying coding, forming categories, and subsequently creating related themes with the help of computer software. Codes or labels given at the initial stage of data analysis are called independent codes using NVIVO 12.0 software. To obtain study reliability and validity, data interpreted by researchers were reviewed by study informants and validated by three content external experts via Cohen Kappa index. Researchers also triangulated interview and observation data sources as well as document content analysis to ensure the validity and reliability of the study data. The data will be synthesized and once the researcher will draw conclusions.

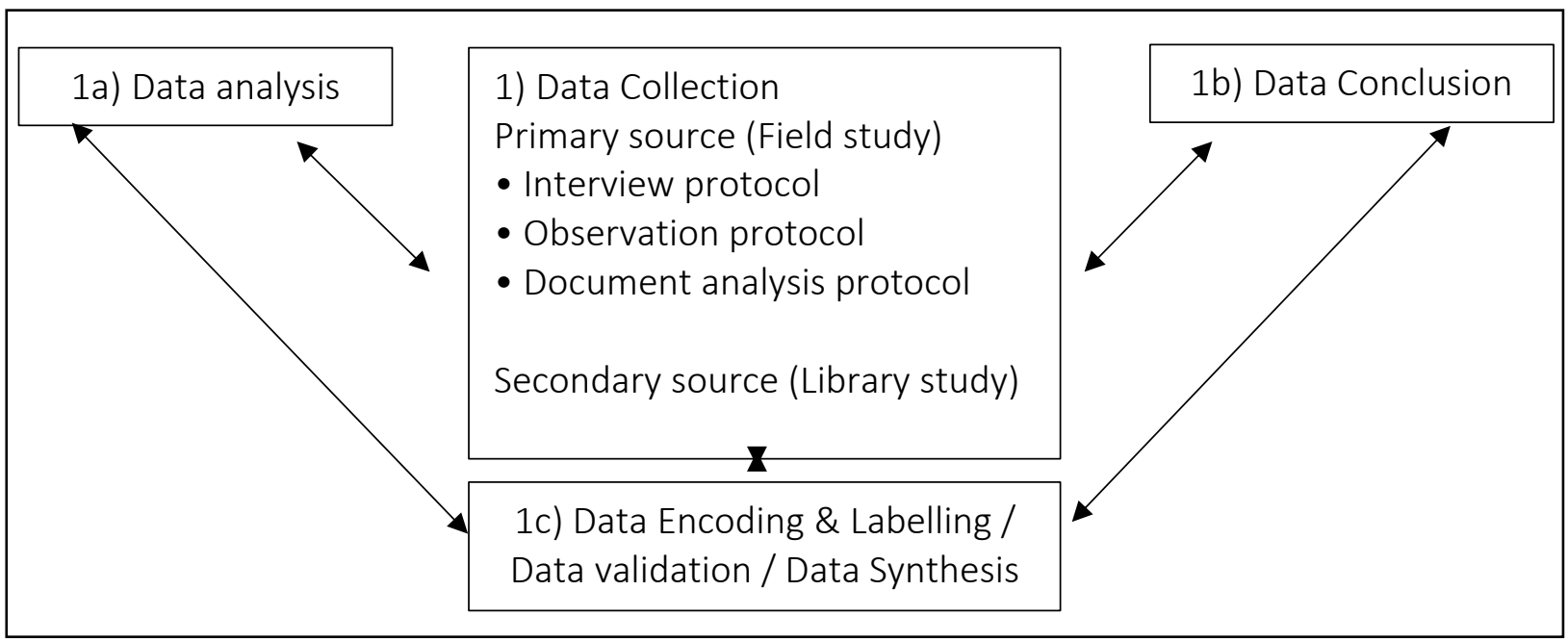




\section{Contribution}

Theoretically, scientific studies on this approach can be applied by the Ministry of Education (MOE) and the Ministry of Higher Education (MOHE) in particular to assist teachers and prospective teachers of specialization and non-specialization especially in contributing to the development of identity teachers by using elements of acting in teaching and learning process. Furthermore, the content knowledge and pedagogical knowledge in this model, the approach can stimulate the development of knowledge and skills of teachers especially teachers who have no background or specialization in the field of theater or drama education. This study produces a guiding framework for becoming the ideal teacher.

Methodologically, this study is also important to realize the eighth shift of "Transformation of Educational Abilities and Delivery Capabilities" contained in the Malaysian Education Development Blueprint 2013-2025. In addition, achieve the goals and objectives of Malaysia Arts School in nurturing students with balanced academic and artistic performance (MOE, 2020).

Practically, the knowledge and acting techniques and approaches of this critical pedagogy can stimulate the development of knowledge and skills of a teacher because this study can help the implementation of Higher Order Thinking Skills (HOTs) towards critical transformation. The application of this study is used by the Ministry of Education (MOE), Ministry of Higher Education (MOHE), State Education Department, and the District Education Department as well as schools under it, which can conduct industrial training, workshops, or programs to improve the skills of teachers including coaching and mentoring programs by using the acting method. This study is expected to contribute to the provision of comprehensive and balanced, critical, creative, innovative human capital as well as aspiration of the ideal students to meet the challenges of the 21st century in line with the direction of the country's transformation towards achieving Vision 2030 and the National Transformation Plan 2050.

\section{Conclusion}

All in all, although various plans and initiatives for applying HOTs in the classroom have been made by the Ministry of Education. The government has more room for improvement. This article will suggest the development of teacher critical pedagogy and education culture to apply HOTs concept or methods in their specific subjects according to Malaysian standards curriculum especially in new curriculum of Theater Arts. It is important to take into account the reality of Malaysia's educational culture, that is, the large-class system and the diverse learners and limited teaching time; applying for HOTs.

Theater techniques are one of the learning mediums that are often applied by teachers. Therefore, this theater technique is seen to have the potential to be applied as one of the main mediums in learning, especially the Theater in Education Program organized by the Ministry of Education Malaysia. Through the programs provided, efforts have been made to stimulate cognitive and hiher order thinking skill change among students so that they are able to lead a social life which in turn exposes them towards the process of building a more robust selfpersonality.

This study offers implications in terms of teacher knowledge and skills. First, this study is extended to explore the development of Malaysian teacher critical pedagogy towards the acting 
method in teaching. As mentioned earlier, this research contributes to filling the existing gaps in research on the education culture in Malaysia that studies have shown the function and importance of the elements of acting in helping to shape more effective teaching quality. A teacher has almost the same role as an actor. Every element that fulfills the nature of a stage play is also present in the teaching system in schools. The tendency of teachers to underestimate the elements of current knowledge, causes them to also underestimate current issues which are in fact more challenging. We are so worried about the weakness of seeing reality now causing us to drift in the wave on education transformation of change that is taking place. Therefore, this study fills the paradigm of the development of teacher quality and deliverability in the implementation of HOTs in Malaysia.

Through this study, it is hoped to provide a contribution in terms of practical, theoretical and methodological in the field of education leading to students with thinking skill. The results obtained in this study are expected to provide practical contributions that may be a solution to the strategy being sought by the Ministry of Education Malaysia (MOE) and the Ministry of Higher Education (MOHE) in an effort to educate students with creative, innovative, and critical thinking. In addition, the introduction or contribution of theory acting method to researchers and readers in this study can provide theoretical contributions that is the latest influence to other researchers. In addition, the contribution of methodology is the method of data collection that will be used by researchers to collect information in this study (case study and observation methods) that can be used as a reference or guide by researchers and readers.

Further research on this study can be applied by the Ministry of Education Malaysia (MOE) and the Ministry of Higher Education (MOHE) in particular to help teachers and prospective teachers in any subjects in contributing to the development of teacher pedagogical content knowledge. A quantitative study involving a large sample is proposed as a further study to deepen the mastery of pedagogical content knowledge of any new subject teachers especially and all subjects generally in a newly revised curriculum. Improving the concept and curriculum framework can also help further studies as well as to improve and develop teacher's quality of pedagogy, knowledge, practice, and identity professionalism in education, provision of resources in curriculum development, and preparation of guidelines and reference of teaching and learning programs or new curriculum in education at the Ministry of Education Malaysia (MOE) or Ministry of Higher Education (MOHE).

\section{Acknowledgment}

This research is a scholarship by the Ministry of Education (MOE) - (Hadiah Latihan Persekutuan, 2020)

\section{Corresponding Author}

Dr. Muhammad Faisal bin Ahmad

Faculty of Music and Performing Arts Sultan Idris Education University Perak, Malaysia

Email:mfaisal@fmsp.upsi.edu.my 
INTERNATIONAL JOURNAL OF ACADEMIC RESEARCH IN PROGRESSIVE EDUCATION AND

DEVELOPMENT

Vol. 10, No. 2, 2021, E-ISSN: 2226-6348 @ 2021 HRMARS

\section{References}

Amir, M. (2019). Kaedah Teater Membaca Dalam Pengajaran Dan Pembelajaran Genre (Drama). Jabatan Bahasa Dan Kesusasteraan Melayu, Universiti Pendidikan Sultan Idris.

Ahmad, M. N. (2008). Seni Lakon Mencerminkan Sikap Masyarakat. Bangi: Penerbit Universiti Kebangsaan Malaysia.

Ahmad., M. F. (2012). Teknik Seni Lakon Dalam Pengajaran: Satu Kajian Kes Di Negeri Selangor. Universiti Kebangsaan Malaysia.

Azmi, M. N., \& Kamarudin, N. (2017). Penerapan Kemahiran Berfikir Aras Tinggi (KBAT): Kesediaan Guru dalam Pengajaran dan Pembelajaran Reka Bentuk dan Teknologi (RBT) di Sekolah Rendah. International Research Journal of Education and Sciences, 1(1), 1-5.

Cathrine, M. (2019). Pengetahuan pedagogi kandungan (ppk) guru bukan pengkhususan reka bentuk dan teknologi (rbt) di sekolah menengah. Malaysian journal of social sciences and humanities (mjssh), 4(6), $64-71$.

Chee, J., Nor, M. M., Othman, A. J., \& Rahman, M. N. A. (2018). Isu Pengetahuan Kandungan, Pedagogi Dan Teknologi Dalam Kalangan Guru Prasekolah. Juku: Jurnal Kurikulum \& Pengajaran asia pasifik, 6(1), 7-21.

Corbin, J., \& Strauss, A. (1990). Grounded Theory Research: Procedures, Canons, and Evaluative Criteria. Qualitative Sociology, 13(1), 3-21.

Elizabeth, A., \& Plessis, D. (2019). Barriers to the effective management of diversity in classroom contexts: The out-of- fi eld teaching phenomenon. International Journal of Educational Research, 93(November 2017), 136-152.

Freire, P. (1970). Pedagogy of the oppressed. Broadway, NY: Bloombury Academic.

Freire, P. (2001). Pedagogy of Freedom Ethics, Democracy and Civic Courage. New York, NY: Rowman \& Littlefield.

Griggs, T. (2001). Teaching as acting: considering acting as epistemology and its use in teaching and teacher preparation. Teacher Education Quarterly, 28(2), 23-37.

Hanning, R. W. (1984). The classroom as the theater of self: some observations for beginning teachers. Retrieved from www.ade.org/ade/bulletin/N077/077033.htm.

Hart, R. (2007). Act like a teacher: Teaching as a Performing Art. Electronic Doctoral Dissertations for UMass Amherst.

Iberahim, A. R., Mahamod, Z., \& Mohamad, W. M. R. W. (2017). 21st Century Learning and the Influence of Attitude, Motivation, and Achievements Malay Language Secondary School Student. Jurnal Pendidikan Bahasa Melayu. ISSN:2180-4842. Vol. 7, Bil. 2 (Nov. 2017): 77 88.

Kam, K., Chan, H., Hin, B., \& Yung, W. (2018). Developing Pedagogical Content Knowledge for Teaching a New Topic: More Than Teaching Experience and Subject Matter Knowledge. Res SciEduc, 48, 233-265.

Kementerian Pendidikan Malaysia. (2013). Pelan Pembangunan Pendidikan Malaysia 2013-2025. Putrajaya: Bahagian Pendidikan Guru.

Kementerian Pendidikan Malaysia. (2017). Dokumen Standard Kurikulum dan Pentaksiran. Seni Teater, Tingkatan 1. Putrajaya: Bahagian Pembangunan Kurikulum.

Krathwohl, D. R. (2002). A revision of Bloom's taxonomy: An overview. Theory into practice 41(4), 212-218. 
Krulik, S., \& Rudnick, J. A. (1999). Innovative Tasks to Improve Critical and Creative Thinking Skills. Developing Mathematical reasoning in Grades K-12, 138-145.

Lakshmi, P., \& Abdul Rahman, M. K. (2020). Aplikasi Teknik Teater Kreatif Dalam Meningkatkan Kesedaran Kognitif Murid-Murid Berkeperluan Khas (Mbk). Journal of Social Science and Humanities, 3 (3), 9-14.

Lembaga Peperiksaan Malaysia. (2013). Elemen kemahiran berfikir aras tinggi (KBAT) dalam instrumen pentaksiran. Putrajaya: Kementerian Pendidikan Malaysia.

Mana Sikana. (2005). Pengajaran dan Pembinaan Bahasa dalam konteks Pendidikan Drama. Jurnal Aktivis 1(5). 116-138.

Nor, M. U. M., Mohamad, Z., \& Badusah, B. (2011). Penerapan Kemahiran Generik Dalam Pengajaran Guru Bahasa Melayu Sekolah Menengah. Jurnal Pendidikan Bahasa Melayu. Universiti Kebangsaan Malaysia.

Nadarajan, T. (2014). Penggunaan teater forum dalam pengajaran dan pembelajaran di sekolah menengah. Kuala Lumpur: Fakulti Pendidikan, Universiti Malaya.

Nixon, R. S., Luft, J. A. \& Ross, R. J. (2017). Prevalence and Predictors of Out-of-Field Teaching in the First Five Years. Journal of Research in Science Teaching, 54(9), 1197-1218.

Paolini, A. (2015). Enhancing Teaching Effectiveness AND Student Learning Outcomes, 15(1), 2033.

Özmen, K. S. (2010). Fostering Nonverbal Immediacy and Teacher Identity Through an Acting Course in English Teacher Education. Australian Journal of Teacher Education, 35 (6).

Özmen, K. S. (2011). Acting and Teacher Education: The Being Model for Identity Development. Turkish Online Journal of Qualitative inquiry, 2(2), 36-49.

Palmer, P. J. (2003). The Heart of a Teacher: Identity and Integrity in Teaching. In the Jossey-bass Reader on Teaching (pp. 3-25). San Francisco: Jossey- Bass.

Bujang, R. (1982). Drama Melayu 25 Tahun. Kuala Lumpur: Dewan Bahasa dan Pustaka.

Rajendran, n. (2001). The Teaching of Higher Order Thinking Skill in Malaysia. Journal of Southeast asian Education, 2(1).

Rajendran, N. (1998b). Teaching higher-order thinking skills in language classrooms in Malaysia; The teachers' dilemmas. Inaugural Conference of the Malaysian EducationalResearch association, Penang Malaysia.

Rives jr., F. C. (1979). The Teacher as a performing artist. Contemporary education, 51(1), 7-9.

Rodgers, C., \& Scott, k. (2008). The development of the personal self and professional identity in learning to teach. In m. Cochran-smith, s. Feiman-nemser, d.j. Mcintyre \& k.e. Demers (eds.), handbook of research on teacher education: enduring questions and changing contexts (pp. 732-755). New york: routledge.

Pusat Perkembangan Kurikulum. (1993). Kemahiran berfikir: Konsep, model dan strategi pengajaran dan pembelajaran. Kuala Lumpur: Pusat Perkembangan Kurikulum.

Saleh, B., Rasul, M. S., \& Affandi, H. M. (2018). Pedagogical practices of design and technology teacher trainees pedagogical practices of design and technology teacher trainees. International journal of academic research in business \& social sciences, 8(5), 319-329.

Salleh, U. K. M., \& Hutagalung, F. (2016). Comparisons of out of field and in-field history teacher: teachers' and students' characteristics. Advanced science letters, 22(8), 1952-1956.

Sarason, s. B. (1999). Teaching as performing art. New york: teachers college press. 
INTERNATIONAL JOURNAL OF ACADEMIC RESEARCH IN PROGRESSIVE EDUCATION AND

DEVELOPMENT

Vol. 10, No. 2, 2021, E-ISSN: 2226-6348 @ 2021 HRMARS

Schechner, R. (2013). Performances studies: An Introduction. (Third Edition). London: Routledge. Shing, C. L., Mohd, S. R., \& Loke, S. H. (2015). The Knowledge of Teaching - Pedagogical Content Knowledge (PCK). The Malaysian Online Journal of Educational Science,3(3), 40-55.

Shulman, I. S. (1987). Knowledge and teaching: foundations of the new reform. Harvard education review, 57(1), 1-22.

Shulman, L. S. (1986). Those Who Understand: Knowledge Growth in Teaching. American Educational Research Association, 15(2), 4-14.

Stanislavsky, c. (2013). An actor prepares. London: bloomsberry publishing.

Stanislavsky, C. (2003). An Actor Prepares. Terjemahan Elizebeth Reynold Hapgood. New York: Routledge.

Stanislavsky, C. (1972). An actor prepares (E. R. Hapgood, Trans.). New York: New York.

Stanislavsky, C. (1949). Building a character (E. R. Hapgood, Trans.). New York: Theatre Arts Books.

Suyanto, S. (2017). A reflection on the implementation of a new curriculum in indonesia: a crucial problem on school readiness. In the 4th international conference on research, implementation, and education of mathematics and science (vol. 100008, pp. 1-9).

Tauber, R. T., \& mester, c. S. (2007). Acting lessons for teachers: using performance skills in the classroom (2nd ed.). Westport, conn: praeger.

Timpson, W. W., \& tobin, D. N. (1982). Teaching as performing: a guide to energizing your public presentation. Englewood, nj: prentice hall inc.

Travers, R. M. W. (1979). Training the teacher as a performing artist. Contemporary education. 51(1), 14-18.

Vandivere, A. H. (2008). An investigation of the nonverbal communication behaviors and role perceptions of pre-service band teachers who participated in theatre seminars. Unpublished ph.d. Dissertation. University of north texas, texas.

Van Hoose, J., \& Hult Jr., R. E. (1979). The performing artist dimension ineffective teaching. Contemporary Education, 51(1), 36-39.

Zakaria, M. A., \& Ahmad, M. F. (2021). Teaching as Performance Studies: Exploring the Pedagogical Content Knowledge (PCK) of Theater Arts. International Journal of Academic Research in Business and Social Sciences, 11(2), 1213-1226.

Zakaria, M. A., \& Ahmad, M. F. (2021). Unsur Seni Lakon Dalam Pengajaran: Satu Pembangunan Identiti Guru. Proceedings of International Conference of Sustainable Social Sciences, Innovation \& Technology (ICSSiT) 2020 (pp. 40-45). Cabaran Semasa dan Inovasi dalam Sistem Pembelajaran dan Pendidikan. elSBN 978-967-18546-5-5. Tanjung Malim, Perak.

Zakaria, M. A., Ahmad, M. F., \& Abdul Rahman, M. K. (2021). Model Pembangunan Identiti Guru: Pendekatan Pengajaran Seni Teater Dalam Pendidikan Di Malaysia. Proceedings of International Conference on Social Sciences and Humanities (ICSSH) 2021 (pp. 173-186). IsuIsu Pendidikan. eISBN 978-967-2908-75-3. Tanjung Malim, Perak. 